\title{
A Cross-sectional Study Evaluating Childhood Autism Awareness of Residents Otorhinolaryngology Department in İstanbul
}

\author{
İstanbul'da Kulak Burun Boğaz Bölümü Asistanlarının Çocukluk Çağı Otizm \\ Farkındalıklarını Değerlendiren Kesitsel Bir Çalışma

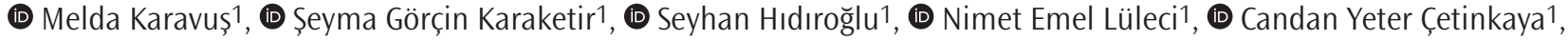 (D) Ezel Bersu Hoşgör ${ }^{1}$, (D) Semih Karaketir², (D) Ahmet Karavuş3

${ }^{1}$ Marmara University Faculty of Medicine, Department of Public Health, İstanbul, Turkey

2University of Health Sciences, Okmeydanı Training and Research Hospital, Clinic of Otorhinolaryngology, İstanbul, Turkey

3University of Health Sciences, Fatih Sultan Mehmet Training and Research Hospital, Clinic of Otorhinolaryngology, İstanbul, Turkey

\begin{abstract}
Introduction: Otorhinolaryngology (ENT) physicians may be effective in the early diagnosis of autism spectrum disorder (ASD). The aim of this study was to investigate the awareness of ENT residents in İstanbul about recognizing ASD.

Methods: The type of the study was cross-sectional. The study population consisted of 97 ENT residents, and 83 (85\%) of these residents were included in the study. The questionnaire consisted of questions about the sociodemographic data of the participants and Autism Spectrum Disorder Awareness Questionnaire. Autism Spectrum Disorder Awareness Questionnaire contains the findings of ASD reported in the literature. This questionnaire includes observable findings of possible ASD in a child during routine examination of the ENT physician.

Results: In our study, the most known finding of childhood autism was found to be difficulty in making eye contact (97.5\%). Regarding work experience, "difficulty in making eye contact" $(100 \%)$ and "lack of age-appropriate language development" (91.5\%) findings were well-known findings among residents with less than four years of experience. On the other hand, "very sensitive vision, hearing and touch senses" (95.8\%) and "seem unable to hear even if hearing tests are normal" (91.7\%) findings were more prominent among residents with four or more years of experience.
\end{abstract}

Conclusion: The ASD awareness of the ENT residents participating in our study can be considered as relatively good. The "Autism Spectrum Disorder Awareness Questionnaire" developed by the researchers is planned to be validated with the studies to be carried out later and developed to be used for ENT specialists. Such questionnaires can also be used to raise awareness among ENT residents and specialists.

Keywords: Awareness, childhood autism, otorhinolaryngology, resident, Turkey öz

Amaç: Kulak burun boğaz (KBB) hekimleri, otizm spektrum bozukluğunun (OSB) erken tanısında etkin olabilir. Bu çalışmanın amacı, İstanbul'daki KBB asistan hekimlerinin OSB'yi tanıma konusundaki farkındalıklarını araștırmaktır.

Yöntemler: Araștırmanın tipi kesitseldir. Çalıșma evrenini KBB uzmanlık alanında çalışan ve uzmanlık eğitimi alan 97 asistan olușturmaktadır ve bu asistanların 83'ü (\%85) çalıșmaya dahil edilmiștir. Soru formu katılımcıların sosyodemografik bilgilerini sorgulayan sorular ve "Otizm Spektrum Bozukluğu Farkındalık Anketi”nden olușmaktadır. Otizm Spektrum Bozukluğu Farkındalık Anketi literatürde bildirilen OSB bulgularını içermektedir. Söz konusu anket KBB hekiminin rutin muayenesinde, bir çocukta olası OSB'nin gözleme dayalı olarak fark edilebilecek bulgularını sorgulamaktadır.

Bulgular: Çalıșmamızda çocukluk çağı otizminin en bilinen bulgusu, göz teması kurmada zorluk çekme olarak bulunmuștur $(\% 97,5)$. Hekimlik yapılan süreye göre katılımcıların OSB bulgularını doğru yanıtlama durumları incelendiğinde, dört yıldan az kıdemi olan asistanların iyi bildiği bulgular arasında "göz teması kurmada güçlük çekme" (\%100) ve "yașına uygun dil gelişiminin geride olması" (\%91,5), dört yıl ve daha fazla kıdeme sahip asistanlar arasında ise "görme, ișitme ve dokunma duyularının çok hassas olması" $(\% 95,8)$ ve "işitme testleri normal olsa bile duymuyormuş gibi gözükebilme" $(\% 91,7)$ bulguları öne çıkmaktadır.

Sonuç: Çalıșmamıza katılan KBB asistanlarının OSB farkındalığı göreceli olarak iyi düzeyde kabul edilebilir. Araștırmacılar tarafından geliștirilen "Otizm Spektrum Bozukluğu Farkındalık Anketi”nin daha sonra gerçekleștirilecek çalıșmalar ile valide edilmesi ve KBB uzmanları için de kullanılabilecek șekilde geliștirilmesi düşünülmektedir. Bu tür anketler, KBB asistanları ve uzmanları arasındaki farkındalığı artırmak için de kullanılabilir.

Anahtar Kelimeler: Farkındalık, çocukluk çağı otizmi, kulak burun boğaz, asistan, Türkiye

Address for Correspondence/Yazıșma Adresi: Șeyma Görçin Karaketir MD, Marmara University Faculty of Medicine,

Department of Public Health, İstanbul, Turkey

Phone: +90 5068951105 E-mail: gorcin_eseyma@hotmail.com ORCID ID: orcid.org/0000-0002-8540-4148

Cite this article as/Atıf: Karavuș M, Karaketir \$̦G, Hıdıroğlu S, Lüleci NE, Yeter Çetinkaya C, Hoșgör EB, Karaketir S, Karavuș A. A Cross-sectional Study Evaluating Childhood Autism Awareness of Residents Otorhinolaryngology Department in İstanbul. İstanbul Med J 2019; 20(5): 450-7.

(c) Copyright 2019 by the Istanbul Training and Research Hospital/istanbul Medical Journal published by Galenos Publishing House.

(C) Telif Hakkı 2019 Istanbul Ĕgitim ve Araștırma Hastanesi/Istanbul Tıp Dergisi, Galenos Yayınevi tarafından basılmıștır. 


\section{Introduction}

Autism spectrum disorder (ASD) is in the group of neuropsychiatric disorders characterized by delay, pause and deviation in social, communicative and cognitive development that started in the first years of life (1). According to the epidemiological statistics published by the United States Center for Disease Control and Prevention and the Autism and Developmental Disabilities Monitoring Network, 1 out of 68 children has ASD diagnosis and its prevalence is increasing rapidly (2). Combining the prevalence of juvenile diabetes mellitus, childhood cancers, and pediatric acquired immunodeficiency syndrome, ASD is more common $(3,4)$. Although the etiology cannot be attributed to a specific cause, it is known that psychosocial factors, neurobiological factors, prenatal and postnatal factors and genetic background may be effective in the emergence of the disease as a phenomenon (5).

Studies have shown that early diagnosis and rapid initiation of appropriate treatment play a key role in the development of communication and social skills (6-10). While diagnosing at an early age is positively associated with developmental outcomes, the effectiveness of interventions may be reduced in older children $(7,8)$. However, it was reported that the time to diagnosis was relatively long when the parent noticed and reported the first symptoms, which led to delayed diagnosis and treatment (8).

The Diagnostic and Statistical Manual of Mental Disorders-5 (DSM-5) ASD diagnostic criteria emphasized abnormal reactivity to sensory stimuli, including sounds, and atypical processing of environmental sounds (11). Many children can first be brought to an otorhinolaryngology (ENT) outpatient clinic for assessment of communication and hearing problems. ASD is a lifelong condition that affects all ages of the ENT patient population (12). However, comorbid conditions such as sleep disorders, food allergies, eczema and asthma are slightly higher in patients with ASD $(13,14)$. In addition to hearing problems, parents of children with autism may also consult an ENT physician with these complaints. This offers ENT physicians the opportunity to assist in the early diagnosis of children with autism. Asking parents a simple question about their child may generate a warning to the doctor for the diagnosis of ASD. For example, the question "Do you have any concerns about your child's physical or behavioral development?" might be helpful. The awareness of ASD is extremely important for ENT physicians to be effective in early diagnosis and intervention (12).

The aim of this study was to define the awareness of ENT residents in İstanbul about recognizing ASD by considering the increase in incidence, the importance of early diagnosis and the fact that the first place of application can be ENT outpatient clinics.

\section{Methods}

After 6 years of medical training, physicians who are eligible to become a general practitioner optionally prefer an area of expertise following success in "Medical Specialization Examination". In this way, they start to work as a resident in Training and Research Hospitals of the Ministry of Health or Medical Faculty Hospitals. This training is usually four or five years and they become specialists after training (15). The reason why the research universe included residents is that it is an important group both in terms of receiving training in the field of expertise and providing health services. First-time practices and experiences during the residency training will also continue in specialist training.

The type of the research was cross-sectional and the research population consisted of ENT residents working in the Training and Research Hospitals in İstanbul. The aim of the study was to reach the whole universe (97 people). The data collection process took place between February and March 2017. The place of the study was 13 hospitals in which ENT residents were working. Informed consent was obtained from the physicians who agreed to participate in the study and participation was made on a voluntary basis. The questionnaire was applied under observation. Residents who could not be reached at the time of the study (being in the operating room, on leave, etc.) were tried to be reached by hospital visit, phone call and message at most three times; failure to respond was accepted as rejection. In addition, participants who left more than $20 \%$ of the questions blank were excluded from the study. Of the 14 people who were not included in the study, four refused to participate, two left the majority of the questions blank and eight could not be reached for various reasons. A total of 83 ENT residents participated in the study. All of the 13 public hospitals in İstanbul, where ENT residents work, were included in our study. Six of these hospitals are located on the European side and seven on the Asian side. The districts where the hospitals were located and the number of assistants included in the study are presented in Table 1.

The questionnaire consists of a 10-item "Individual Questionnaire" and "Autism Spectrum Disorder Awareness Questionnaire" which includes 19 questions measuring the knowledge and awareness about ASD. Within the scope of the Individual Questionnaire, the age, gender, hospital of training, years of experience as a physician and ENT resident, and the presence of someone diagnosed with ASD in their environment were questioned. In addition, the physicians were asked questions about whether a child with ASD had previously applied, and if so, the reasons for the application, and whether the physicians had previously

\begin{tabular}{|l|l|l|l|l|}
\hline \multicolumn{3}{|l|}{$\begin{array}{l}\text { Table 1. The districts where the hospitals were located and the } \\
\text { number of residents included in the study }\end{array}$} \\
\hline Hospital code & District/County & $\begin{array}{l}\text { The number of residents } \\
\text { enrolled in the study }\end{array}$ \\
\hline A & Ümraniye & 5 \\
\hline B & Pendik & 8 \\
\hline C & Ataşehir & 4 \\
\hline D & Göztepe & 8 \\
\hline E & Üsküdar & 7 \\
\hline F & Üsküdar & 4 \\
\hline G & Kartal & 1 \\
\hline H & Bakırköy & 6 \\
\hline I & Şişli & 5 \\
\hline J & Şişli & 8 \\
\hline K & Bağclar & 9 \\
\hline L & Fatih & 9 \\
\hline M & Fatih & 9 \\
\hline Total & & 83 \\
\hline
\end{tabular}


referred for suspected ASD for further examination and diagnosis, and if so, the number of referrals. "Autism Spectrum Disorder Awareness Questionnaire" is a questionnaire containing the findings that can be evaluated during a routine ENT examination of a possible ASD child and suggesting possible ASD, and consists of two parts as "basic questions" and "optional questions". This questionnaire was prepared in the light of the current literature $(11,16-23)$ to observe a possible ASD in a child who applied to an ENT physician for any reason. The basic part questions the findings that are important to be known by physicians, and are more common and easier to recognize and consists of 19 questions. The optional part questions the findings that can be brought to light with the symptoms asked to the family with more examination and consists of 17 questions. The optional part is left to the physician's choice considering the workload of the resident. Seventy-eight participants answered the optional part. The questionnaire was prepared in Likert type and the answer options were "definitive finding", "supportive finding", "Not sure/l do not know", and "Not related to autism". All sentences are definitive or supportive findings in ASD.

\section{Ethics Committee Approval}

The authors declared that the study was conducted in accordance with the principles of the "Ethical Principles for Medical Research Involving Human Subjects" of World Medical Association Declaration of Helsinki. Ethics Committee approval was received from Marmara University Faculty of Medicine Clinical Research Ethics Committee (approval number: 09.2016.651, date: 02.12.2016). The authors have no conflict of interest to declare in this study. The authors declared that this study has received no financial support.

\section{Statistical Analysis}

In statistical analysis, frequency and percentage were used for tabulation of categorical variables and mean and standard deviation were used for presentation of measurable variables.

\section{Results}

This cross - sectional study was conducted in 13 public hospitals in Istanbul by the researchers and a survey was conducted to 83 ENT residents under observation. While $82 \%$ of the participants were male, the mean age was $28.24 \pm 2.90$ years. The number of residents with a child with ASD diagnosis in their environment was four. Forty-two point two percent of the participants stated that they referred at least one child who applied for routine ENT examination with suspicion of ASD for further diagnosis. Table 2 presents the general characteristics of the participants and their exposure to the patient with ASD.

The participants were asked with an open-ended question about why children diagnosed with ASD frequently applied. Forty-two percent $(n=35)$ of the residents reported that they were consulted most commonly with hearing problems and hearing screening, and $12 \%$ $(n=10)$ reported delay in speech. Other less commonly reported reasons for application were acute otitis media, sinusitis and nasal obstruction. Another open-ended question was what could be done in the diagnosis/ follow-up of ASD in the specialty of ENT. The most common response was "demand for training of physicians about the findings and features of ASD" with 19\% $(n=16)$. Other responses were reported as "Which cases will be referred to where", "How hearing and speech therapy can be given to patients", and "Request to extend the examination period to obtain a more detailed anamnesis".

When the responses of the participants to the sentences evaluating their awareness were examined, the most well-known finding was "Difficulty in making eye contact" and $64.6 \%$ of the participants stated it as definitive finding, and $32.9 \%$ described it as a supportive finding. Thirtyone point three percent of the participants stated "Age-appropriate

\begin{tabular}{|c|c|c|}
\hline Variable & $\mathrm{n}$ & $\%$ \\
\hline \multicolumn{3}{|l|}{ Gender } \\
\hline Female & 15 & 18.1 \\
\hline Male & 68 & 81.9 \\
\hline Age $\left(\right.$ mean $\left.\pm S D^{*}\right)$ & \multicolumn{2}{|c|}{$28.24 \pm 2.90$} \\
\hline \multicolumn{3}{|l|}{ Work Hospital } \\
\hline Faculty of medicine hospital & 34 & 41.0 \\
\hline Training and research hospital & 49 & 59.0 \\
\hline \multicolumn{3}{|l|}{ Duration of medical experience } \\
\hline Less than 1 year & 6 & 7.2 \\
\hline $1-4$ years & 53 & 63.9 \\
\hline 4 years and more & 24 & 28.9 \\
\hline \multicolumn{3}{|l|}{ Duration of ENT residency } \\
\hline Less than 1 year & 26 & 32.1 \\
\hline $1-4$ years & 44 & 54.3 \\
\hline 4 years and more & 11 & 13.6 \\
\hline \multicolumn{3}{|c|}{ The presence of someone diagnosed with ASD in your environment } \\
\hline Yes & 4 & 4.8 \\
\hline No & 79 & 95.2 \\
\hline \multicolumn{3}{|l|}{ Application status of a child diagnosed with ASD } \\
\hline Yes & 57 & 68.7 \\
\hline No & 26 & 31.3 \\
\hline \multicolumn{3}{|c|}{$\begin{array}{l}\text { Referring the child with another complaint for further investigation o } \\
\text { suspicion of ASD }\end{array}$} \\
\hline Yes & 35 & 42.2 \\
\hline No & 48 & 57.8 \\
\hline \multicolumn{3}{|l|}{ Number of patients referred with suspicion of ASD } \\
\hline 1 & 2 & 10.5 \\
\hline 2 & 5 & 26.3 \\
\hline 3 and more & 12 & 63.2 \\
\hline \multicolumn{3}{|l|}{ Referred department } \\
\hline Child and adolescent psychiatry outpatient clinic & 22 & 75.9 \\
\hline Request further examination & 7 & 24.1 \\
\hline \multicolumn{3}{|c|}{$\begin{array}{l}\text { Do you think you need training to guide such a child for further } \\
\text { examination/diagnosis? }\end{array}$} \\
\hline Yes & 60 & 80.0 \\
\hline No & 15 & 20.0 \\
\hline
\end{tabular}


language development in children with ASD is delayed" as definitive finding and $57.8 \%$ as supportive finding. The other well-known finding was that "Children with ASD may have very sensitive vision/hearing and touch sensations (such as closing their ears and not letting being touched when they hear some sounds)", and $83.1 \%$ of the respondents described this finding as definitive or helpful. The basic questions regarding the awareness and knowledge residents about ASD are presented in Table 3.

When the responses of the participants to the optional questions about ASD awareness were examined, "Children with ASD have difficulty in social communication" was expressed by all participants as a finding of ASD. Sixty point three percent of physicians reported this finding as definitive finding and 39.7\% reported as supportive finding. "Children with ASD have difficulty in establishing a friendship" was one of the other commonly known statements (definitive finding; 51.3\%, supportive finding; 46.2\%). Another statement with high awareness level was "Children with ASD may show intense interest in certain things/areas" (definitive finding; 48.1\%, supportive finding; 42.9\%). Optional questions and answers regarding the awareness and knowledge of residents about ASD are presented in Table 4.

Table 5 compares the duration of medical experience and the correct response status of ASD findings. Since all of the questions directed to the participants in this comparison were either the definitive or supportive findings of autism, the answers "definitive finding" and "supportive finding" were combined and coded as "finding". The other two answers "Not sure/l do not know" and "Not related to autism" were combined and coded as "not a finding". The duration of medical experience was divided into two groups as "less than four years" and "four years and more". When the correct responses of the participants to ASD findings in terms of duration of medical experience were examined, "difficulty in making eye contact" (100\%) and "lack of age-appropriate language development" (91.5\%), and "limited social smiling" (84.7\%) findings were well-known findings among residents with less than four years of experience. On the other hand, "very sensitive vision, hearing and touch senses" (95.8\%), "difficulty in making eye contact" (91.7\%), and "seem unable to hear even if hearing tests are normal" (91.7\%) findings were more prominent among residents with four or more years of experience. Table 5 presents the comparison of the duration of medical experience and the correct response status of the participants to the ASD findings.

\section{Discussion}

In the literature, awareness of ASD has been evaluated in many groups such as pediatricians, psychiatrists, neurologists, family physicians, pharmacists, educators, psychologists, and speech therapists throughout the society $(3,16,17,22,24)$. One of the early medical contacts of children who have not yet been diagnosed with ASD may be with ENT physicians whom they are brought with suspicion of hearing and communication problems. The knowledge and awareness of ENT physicians about ASD symptoms is critical for early diagnosis (11). In this study, ASD awareness was evaluated in ENT residents, a group both receiving education and offering health services.

Table 3. Basic questions about autism spectrum disorder awareness and knowledge of otorhinolaryngology residents $(n=83)$

\section{Questions}

Children with ASD do not look at their name

Age-appropriate language development is delayed in children with ASD

Children with ASD have difficulty making eye contact

Children with ASD have difficulty in nonverbal communication

Children with ASD have stereotypic and repetitive behaviors

Children with ASD may have very sensitive vision/hearing and touch senses (such as closing their ears and not letting being touched when they hear some sounds)

Children with ASD have limited social smiling

Children with ASD use pronouns upside down (confuse me and you

Children with ASD may appear to be unable to hear even if their hearing tests are norma

Children with ASD have difficulty understanding other people's body language

Children with ASD have difficulty understanding other people's gestures

Children with ASB may clap their hands from time to time

Children with ASD sometimes walk at their fingertips/revolve around themselves

Children with ASD find it difficult to imitate the people around them

Children with ASD say some pattern sentences/words to themselves over and over again

Children with ASD have a hard time showing what they want

Echolalia/parrot speech can be found in children with ASD

Children with ASD have limited use of simple body language such as "make bye-bye"

Children with ASD have difficulty in understanding and fulfilling orders

ASD: autism spectrum disorder, ENT: otorhinolaryngology

\begin{tabular}{|c|c|c|c|c|c|c|c|}
\hline \multicolumn{8}{|c|}{ Number (\%) } \\
\hline \multicolumn{2}{|c|}{$\begin{array}{l}\text { Definitive } \\
\text { finding }\end{array}$} & \multicolumn{2}{|c|}{$\begin{array}{l}\text { Supportive } \\
\text { finding }\end{array}$} & \multicolumn{2}{|c|}{$\begin{array}{l}\text { Not related to } \\
\text { autism }\end{array}$} & \multicolumn{2}{|c|}{$\begin{array}{l}\text { Not sure/I do } \\
\text { not know }\end{array}$} \\
\hline 13 & (14.6) & 55 & $(67.1)$ & 7 & (8.5) & 8 & (9.8) \\
\hline 26 & (31.3) & 48 & $(57.8)$ & 5 & $(6.0)$ & 4 & $(4.8)$ \\
\hline 53 & (64.6) & 27 & (32.9) & 1 & $(1.2)$ & 1 & $(1.2)$ \\
\hline 23 & $(28.4)$ & 34 & $(42.0)$ & 11 & (13.6) & 13 & $(16.0)$ \\
\hline 36 & $(43.9)$ & 26 & (31.7) & 14 & $(17.1)$ & 6 & (7.3) \\
\hline 32 & (38.6) & 37 & $(44.6)$ & 9 & (10.8) & 5 & $(6.0)$ \\
\hline 24 & $(28.9)$ & 43 & $(51.8)$ & 9 & $(10.8)$ & 7 & $(8.4)$ \\
\hline 5 & $(6.2)$ & 26 & $(32.1)$ & 21 & $(25.9)$ & 29 & (35.8) \\
\hline 20 & (24.1) & 49 & $(59.0)$ & 10 & (12.0) & 4 & $(4.8)$ \\
\hline 19 & (23.2) & 46 & $(56.1)$ & 7 & (8.5) & 10 & (12.2) \\
\hline 20 & $(24.7)$ & 38 & (46.9) & 13 & (16.0) & 10 & (12.3) \\
\hline 15 & (18.3) & 38 & $(46.3)$ & 13 & $(15.9)$ & 16 & $(19.5)$ \\
\hline 10 & $(12.0)$ & 26 & (31.3) & 24 & $(28.9)$ & 23 & $(27.7)$ \\
\hline 3 & $(3.7)$ & 29 & (35.8) & 24 & (29.6) & 25 & (30.9) \\
\hline 23 & $(28.0)$ & 38 & $(46.3)$ & 13 & $(15.9)$ & 8 & $(9.8)$ \\
\hline 8 & $(9.6)$ & 29 & (34.9) & 20 & (24.1) & 26 & (31.3) \\
\hline 7 & $(8.4)$ & 31 & (37.3) & 20 & (24.1) & 25 & (30.1) \\
\hline 8 & $(9.9)$ & 38 & $(46.9)$ & 17 & $(21.0)$ & 18 & $(22.2)$ \\
\hline 13 & $(15.7)$ & 48 & $(57.8)$ & 11 & (13.3) & 11 & (13.3) \\
\hline
\end{tabular}


DSM-5 ASD diagnostic criteria emphasized the atypical processing of environmental sounds (25). In addition, the relative indifference towards human voice of children with ASD is known (26). While $23.8 \%$ of ENT residents answered as "definitive finding" to "Children with ASD may seem to be unable to hear even if their hearing tests are normal", 59.5\% answered as "supportive finding". In our study, this finding can be interpreted as a finding with high awareness.

The American Academy of Pediatrics recommends that a child should be screened for routine development and autism when the child is 18 to 30 months old or at any time, if the caregiver has concerns about the ASD findings (27). Every child with ASD may need to be screened for speech and language development, and every child with these symptoms should be screened for ASD (27). Lack of language development may differ among children with ASD; some may not speak at all, others may have delayed language development $(4,28)$. In our study, $89.1 \%$ of the respondents stated "Age-appropriate language development in children with ASD is delayed" as a definitive or supportive finding, so this can be interpreted as being known to a great extent.

In our study, 50\% of the participants stated "Most of the children with ASD have superior skills in painting, music, mathematics and computer technologies" as definitive or supportive findings. Approximately $25.6 \%$ evaluated this finding as not related to ASD. It is known that $46 \%$ of those diagnosed with ASD have an average or above average intellectual functioning $(4,29)$. While approximately half of the participants reported "Most of the children with ASD have strong memories" as definitive or supportive findings, $35.9 \%$ stated that they did not know the relationship of this finding with autism or were not sure about the relationship with autism. It is important for health professionals to recognize that children with ASD may have abilities that are indicative of higher intellectual functioning than expected, as it may mask the diagnosis of ASD and lead to a delay in diagnosis.

The most known finding by participants was having difficulty in making eye contact. While $64.6 \%$ of the participants stated that it was a definitive finding, $32.9 \%$ described it as a supportive finding. Because there is no laboratory test or biological marker to diagnose a child with ASD, it is very important to carefully observe the behavior of children (30). Eye contact may be weak or absent in patients with ASD (12). In an autism awareness study conducted in pharmacists in Istanbul, more than half of pharmacists reported that there was limited or no eye contact as an ASD finding (17). In a study conducted on primary school teachers, approximately half of the participants stated that they thought that children with ASD had difficulty in making eye contact (31).

In our study, having difficulty in establishing a friendship was defined by the participants as a definitive finding of autism by $60.3 \%$ and a supportive finding by $39.7 \%$. Almost all of the participants attributed this finding to autism. "Making friends" is an issue that children are challenged, as reported by the parents of children with ASD in Dillenburger et al. (16) study. In another study, it was stated that children with ASD wanted to be friends with others but they did not have the ability to maintain friendship (32).

One of the well-known findings by the participants was that vision/ hearing and tactile sensations of children with ASD may be very sensitive, such as closing their ears and not letting being touched when

\section{Table 4. Optional part questions and answers about assistant physicians' awareness and knowledge of autism spectrum disorder ( $\mathrm{n}=78$ )}

Questions

Children with ASD cannot play imaginary games

ASD starts in early childhood

Children with ASD have difficulty establishing a relationship with friends

Children with ASD have difficulty in social communication

Children with ASD have anger attacks

Children with ASD like sameness/resist changes

Children with ASD have routines

Children with ASD may show intense interest in certain things/areas

Children with ASD have difficulties focusing on jobs outside their interests

Children with ASD have difficulty finding the object pointed by the finger

Children with ASD are sensitive to smell and taste

Children with ASD sometimes stare into space

Children with ASD will not open their arms and run towards the other person

Children with ASD may not want to share an object with others

Children with ASD may have different eating habits than their peers

Most children with ASD have strong memories

Many children with ASD have outstanding skills in painting, music, mathematics and computer technologies

ASD: autism spectrum disorde

\section{Number (\%)}

\begin{tabular}{|c|c|c|c|c|c|c|c|}
\hline \multicolumn{2}{|c|}{ Definitive finding } & \multicolumn{2}{|c|}{$\begin{array}{l}\text { Supportive } \\
\text { finding }\end{array}$} & \multicolumn{2}{|c|}{$\begin{array}{l}\text { Not sure/I do } \\
\text { not know }\end{array}$} & \multicolumn{2}{|c|}{$\begin{array}{l}\text { Not related to } \\
\text { autism }\end{array}$} \\
\hline 3 & (3.9) & 19 & (24.7) & 22 & (28.6) & 33 & (42.9) \\
\hline 38 & (48.7) & 27 & (34.6) & 5 & (6.4) & 8 & (10.3) \\
\hline 40 & (51.3) & 36 & $(46.2)$ & 1 & (1.3) & 1 & (1.3) \\
\hline 47 & (60.3) & 31 & (39.7) & 0 & 0 & 0 & 0 \\
\hline 24 & (30.8) & 35 & $(44.9)$ & 7 & (9.0) & 12 & (15.4) \\
\hline 31 & (39.7) & 35 & (44.9) & 7 & (9.0) & 5 & (6.4) \\
\hline 34 & (43.6) & 31 & (39.7) & 9 & (11.5) & 4 & (5.1) \\
\hline 37 & (48.1) & 33 & $(42.9)$ & 5 & (6.5) & 2 & (2.6) \\
\hline 36 & $(46.2)$ & 36 & $(46.2)$ & 4 & (5.1) & 2 & (2.6) \\
\hline 9 & (11.5) & 27 & (34.6) & 24 & (30.8) & 18 & (23.1) \\
\hline 10 & (13.0) & 18 & $(23.4)$ & 35 & $(45.5)$ & 14 & $(18.2)$ \\
\hline 15 & (19.2) & 31 & (39.7) & 21 & (26.9) & 11 & (14.1) \\
\hline 11 & (14.3) & 24 & (31.2) & 25 & (32.5) & 17 & (22.1) \\
\hline 14 & $(17.9)$ & 35 & $(44.9)$ & 16 & $(20.5)$ & 13 & $(16.7)$ \\
\hline 13 & $(16.7)$ & 35 & $(44.9)$ & 21 & (26.9) & 9 & (11.5) \\
\hline 9 & $(11.5)$ & 27 & $(34.6)$ & 28 & (35.9) & 14 & (17.9) \\
\hline 12 & (15.4) & 27 & (34.6) & 19 & $(24.4)$ & 20 & (25.6) \\
\hline
\end{tabular}


they hear some sounds. Eighty-three point two percent of the residents stated "sensory sensitivity" as a finding. In addition, while approximately half of the participants reported "Children with ASD do not open their arms and run towards the other person" as a finding, one third stated that they were not sure or did not know. Avoidance from hug or contact is a relatively less known feature among the participants. In 2015, Biyani et al. (12) provided a comprehensive guide to the management of children with ASD for ENT practice. In this study, it was reported that patients with ASD might have delayed fine motor skills, their voice tone might not be compatible with expressed emotions, and they might have difficulty in empathizing. Avoidance from hug or contact was described as a symptom. Other specific features related to ASD are the fact that the thought process is mostly concrete, having difficulty in understanding literary expressions and idioms, and hypersensitivity to loud sounds, bright lights and strong odors $(4,12,25,29)$.

The characteristics of ASD known by the residents according to the duration of medical experience were examined. Almost all of the residents who have been assistants for four years or more have described

Table 5. Comparison of the duration of the medical experience and the correct response status of the autism spectrum disorder findings of the participants

\begin{tabular}{|c|c|c|c|c|c|}
\hline & & \multicolumn{4}{|c|}{ Duration of medical experience } \\
\hline & & \multicolumn{2}{|c|}{$<4$ years } & \multicolumn{2}{|c|}{$\geq 4$ years } \\
\hline & & $\mathbf{n}$ & $\%$ & $\mathbf{n}$ & $\%$ \\
\hline \multirow{2}{*}{ Children with ASD do not look at their name } & Not a finding & 9 & 15.5 & 6 & 25.0 \\
\hline & Finding & 49 & 84.5 & 18 & 75.0 \\
\hline \multirow{2}{*}{ Age-appropriate language development is delayed in children with ASD } & Not a finding & 5 & 8.5 & 4 & 16.7 \\
\hline & Finding & 54 & 91.5 & 20 & 83.3 \\
\hline \multirow{2}{*}{ Children with ASD have difficulty making eye contact } & Not a finding & 0 & 0 & 2 & 8.3 \\
\hline & Finding & 58 & 100 & 22 & 91.7 \\
\hline \multirow{2}{*}{ Children with ASD have difficulty in nonverbal communication } & Not a finding & 15 & 25.9 & 9 & 39.1 \\
\hline & Finding & 43 & 74.1 & 14 & 60.9 \\
\hline \multirow{2}{*}{ Children with ASD have stereotypic and repetitive behaviors } & Not a finding & 15 & 25.4 & 5 & 21.7 \\
\hline & Finding & 44 & 74.6 & 18 & 78.3 \\
\hline \multirow{2}{*}{$\begin{array}{l}\text { Children with ASD may have very sensitive vision/hearing and touch senses (such as closing their } \\
\text { ears and not letting to be touched when they hear some sounds) }\end{array}$} & Not a finding & 13 & 22.0 & 1 & 4.2 \\
\hline & Finding & 46 & 78.0 & 23 & 95.8 \\
\hline \multirow{2}{*}{ Children with ASD have limited social smiling } & Not a finding & 9 & 15.3 & 7 & 29.2 \\
\hline & Finding & 50 & 84.7 & 17 & 70.8 \\
\hline \multirow{2}{*}{ Children with ASB use pronouns upside down (confuse me and you) } & Not a finding & 31 & 53.4 & 19 & 82.6 \\
\hline & Finding & 27 & 46.6 & 4 & 17.4 \\
\hline \multirow{2}{*}{ Children with ASD may appear to be unable to hear even if their hearing tests are normal } & Not a finding & 12 & 20.3 & 2 & 8.3 \\
\hline & Finding & 47 & 79.7 & 22 & 91.7 \\
\hline \multirow{2}{*}{ Children with ASD have difficulty understanding other people's body language } & Not a finding & 13 & 22.4 & 4 & 16.7 \\
\hline & Finding & 45 & 77.6 & 20 & 83.3 \\
\hline \multirow{2}{*}{ Children with ASD have difficulty understanding other people's gestures } & Not a finding & 15 & 26.3 & 8 & 33.3 \\
\hline & Finding & 42 & 73.7 & 16 & 66.7 \\
\hline \multirow{2}{*}{ Children with ASB may clap their hands from time to time } & Not a finding & 22 & 37.3 & 7 & 30.4 \\
\hline & Finding & 37 & 62.7 & 16 & 69.6 \\
\hline \multirow{2}{*}{ Children with ASD sometimes walk at their fingertips/revolve around themselves } & Not a finding & 37 & 62.7 & 10 & 41.7 \\
\hline & Finding & 22 & 37.3 & 14 & 58.3 \\
\hline \multirow{2}{*}{ Children with ASD find it difficult to imitate the people around them } & Not a finding & 35 & 59.3 & 14 & 63.6 \\
\hline & Finding & 24 & 40.7 & 8 & 36.4 \\
\hline \multirow{2}{*}{ Children with ASD say some pattern sentences/words to themselves over and over again } & Not a finding & 18 & 31.0 & 3 & 12.5 \\
\hline & Finding & 40 & 69.0 & 21 & 87.5 \\
\hline \multirow{2}{*}{ Children with ASD have a hard time showing what they want } & Not a finding & 32 & 54.2 & 14 & 58.3 \\
\hline & Finding & 27 & 45.8 & 10 & 41.7 \\
\hline \multirow{2}{*}{ Echolalia/parrot speech can be found in children with ASD } & Not a finding & 35 & 59.3 & 10 & 41.7 \\
\hline & Finding & 24 & 40.7 & 14 & 58.3 \\
\hline \multirow{2}{*}{ Children with ASD have limited use of simple body language, such as "making bye-bye" } & Not a finding & 27 & 47.4 & 8 & 33.3 \\
\hline & Finding & 30 & 52.6 & 16 & 66.7 \\
\hline \multirow{2}{*}{ Children with ASD have difficulty in understanding and fulfilling orders } & Not a finding & 14 & 23.7 & 8 & 33.3 \\
\hline & Finding & 45 & 76.3 & 16 & 66.7 \\
\hline
\end{tabular}


"Vision, hearing and tactile sensations can be very sensitive" as an ASD finding. Sensory sensitivity is a finding that can be easily noticed in the clinic. An ENT physician, who can detect signs such as closing his/her ears and not letting being touched when he/she hears some sounds, can easily suspect ASD and refer the child for further evaluation. Some findings such as seeming unable to hear even if hearing tests are normal are less known among physicians with a shorter duration of medical experience compared to those with more experience. It may be useful to focus on resident training by identifying lesser-known symptoms.

\section{Strengths and Limitations of the Study}

As a first step, due diligence should be made before initiatives to raise awareness on ASD. This study is the first known study in the literature to determine the awareness of ASD among ENT residents. In addition, the study was conducted in a large sample of all ENT residents in 13 public hospitals in Istanbul. The questions about the awareness of ASD used in our study question the findings that are important to be known by physicians, and are more common and more easily noticed. All of the questions are findings of ASD and the questionnaire can be instructive in this respect.

In our study, all of the sentences are a possible finding of ASD. The fact that our questionnaire was designed in this way is also intended to be instructive for residents receiving ENT specialist training. A statement that was not a finding was not included in the questionnaire in order to ensure that false statements are not catchy.

In our study, some questions about childhood autism are not included. Although these questions are used in screening tests, choosing more specific questions for ENT examination in terms of OCD awareness may be a limitation. In addition, the results of this study cannot be generalized to all residents in Turkey. This study, using a questionnaire completed by the participant himself/herself under observation, may have caused desirability bias to provide correct answers.

\section{Conclusion}

Autism awareness of the participants in our study can be considered as relatively good. Participants represent a group that has not yet become an ENT specialist, receiving training and providing health care. In addition to hearing disorders, comorbid medical disorders including sleep disorders, food allergies, eczema and asthma are more common in patients with ASD; ENT physicians should be careful and rigorous in terms of $\operatorname{ASD}(13,14)$. Analogs of this study should be applied to both residents and specialists in other ENT clinics and a situation determination should be made. If awareness of ASD can be integrated into ENT specialist training curriculum or bedside practices in outpatient clinic, especially early diagnosis and intervention can go to very high levels. This can be considered as a requirement considering the rapid increase in the prevalence of ASD.

Adequate knowledge and awareness of childhood autism among ENT residents will enable early detection of children with autism in the community, which will allow for early intellectual, social and behavioral interventions. The questionnaire used in this study is intended to be developed by the researchers as "Autism Awareness Scale in
Otorhinolaryngology Physicians". This scale can be used later in other cities in Turkey and can contribute to early diagnosis of ASD in Turkey.

Ethics Committee Approval: Ethics committee approval was received from Marmara University Faculty of Medicine Clinical Research Ethics Committee (approval number: 09.2016.651, date: 02.12.2016).

Informed Consent: Informed consent was obtained from the physicians who agreed to participate in the study and participation was made on a voluntary basis.

Peer-review: Externally peer-reviewed.

Author Contributions: Concept - M.K., S.G.K., S.H., A.K.; Design - M.K., S.G.K., S.H., N.E.L.; Data Collection and/or Processing - M.K., Ş.G.K., S.H., C.Y.C.., E.B.H., S.K.; Analysis and/or Interpretation - M.K., N.E.L.; Literature Search - M.K., S.G.K., N.E.L., S.K., Writing Manuscript - M.K., Ş.G.K., C.Y.C.., E.B.H.

Conflict of Interest: No conflict of interest was declared by the authors.

Financial Disclosure: The authors declared that this study received no financial support.

\section{References}

1. Volkmar FR, Lord C, Bailey A, Schultz RT, Klin A. Autism and pervasive developmental disorders. J Child Psychol Psychiatry 2004; 45: 135-70.

2. Wingate M, Kirby RS, Pettygrove S. Prevalence of autism spectrum disorders among children aged 8 years autism and developmental disabilities monitoring network, 11 sites United States, 2010. MMWR Surveill Summ 2014; 63: $1-21$.

3. Khanna R, Jariwala K. Awareness and knowledge of autism among pharmacists Res Social and Adm Pharm 2012; 8: 464-71.

4. Autism Speaks. What is autism? 2016 (cited 2018 December 5) Available from: URL: http://www.autismspeaks.org/what-autism

5. Bilgic A, Uslu R, Özalp Kartal O. Comparison of toddlers with pervasive developmental disorders and developmental delay based on diagnosis classification: 0-3 Revised. Archives of Neuropsychiatry/Noropsikiatri Arșivi 2011; 48: p188-194.

6. Arif MM, Niazy A, Hassan B, Ahmed F. Awareness of autism in primary school teachers. Autism Research and Treatment 2013

7. Liu Y, Li J, Zheng Q, Zaroff CM, Hall BJ, Li X, et al. Knowledge, attitudes, and perceptions of autism spectrum disorder in a stratified sampling of preschool teachers in China. BMC Psychiatry 2016; 16: 142.

8. Wang J, Zhou X, Xia W, Sun C, Wu L, Wang J. Autism awareness and attitudes towards treatment in caregivers of children aged 3-6 years in Harbin, China. Social Psychiatry 2012; 47: 1301-8.

9. Långh U, Hammar M, Klintwall L, Bölte S. Allegiance and knowledge levels of professionals working with early intensive behavioural intervention in autism. Early Interv Psychiatry 2017; 11: 444-50.

10. Lian WB, Ying SH, Tean SC, Lin DC, Lian YC, Yun HL. Pre-school teachers' knowledge, attitudes and practices on childhood developmental and behavioural disorders in Singapore. J Paediatr Child Health 2008; 44: 187-94.

11. Rice CE, Rosanoff M, Dawson G, Durkin MS, Croen LA, Singer A, et al. Evaluating changes in the prevalence of the autism spectrum disorders (ASDs). Public Health Rev 2012; 34: 1-22.

12. Biyani S, Morgan PS, Hotchkiss K, Cecchini M, Derkay CS. Autism spectrum disorder 101: A primer for pediatric otolaryngologists. Int J Pediatr Otorhinolaryngol 2015; 79: 798-802. 
13. Levy SE, Mandell DS, Schultz RT. Autism. Lancet 2009; 374: 1627-38.

14. Zerbo O, Leong A, Barcellos L, Bernal P, Fireman B, Croen LA. Immune mediated conditions in autism spectrum disorders Brain, Behavior, and Immunity 2015; 46: 232-6.

15. Gün I, Öztürk A, Öztürk Y. Erciyes Üniversitesi Tıp Fakültesi intern doktorlarının tıp eğitimine ve tıpta uzmanlık sınavına bakıșlarının değerlendirilmesi. Toplum ve Hekim 2004; 19: 154-8.

16. Dillenburger K, Jordan JA, McKerr L, Devine P, Keenan M. Awareness and knowledge of autism and autism interventions: A general population survey. Research in Autism Spectrum Disorders 2013; 7: 1558-67.

17. Luleci NE, Hidiroglu S, Karavus M, Karavus A, Sanver FF, Ozgur F, et al. The pharmacists' awareness, knowledge and attitude about childhood autism in Istanbul. Int J Clin Pharm 2016; 38: 1477-82.

18. Kara B, Mukaddes NM, Altınkaya I, Güntepe D, Gökçay G, Özmen M. Using the Modified Checklist for Autism in Toddlers in a well-child clinic in Turkey: Adapting the screening method based on culture and setting. Autism 2014; 18: 331-8.

19. Shamsudin S, Rahman Abdul S. A preliminary study: awareness, knowledge and attitude of people towards children with autism. Proceeding of the Social Sciences Research ICSSR 2014; 6: 322-32.

20. Rahbar MH, Ibrahim K, Assassi P. Knowledge and attitude of general practitioners regarding autism in Karachi, Pakistan. J Autism Dev Disord 2011; 41: $465-74$.

21. Sabuncuoglu M, Cebeci S, Rahbar MH, Hessabi M. Autism spectrum disorder and attention deficit hyperactivity disorder: Knowledge and attitude of family medicine residents in Turkey. Turkish Journal of Family Medicine \& Primary Care 2015; 9: 46-53.

22. Hartley-McAndrew M, Doody KR, Mertz J. Knowledge of autism spectrum disorders in potential first-contact professionals North American Journal of Medical Sciences 2014; 7: 97-102.
23. Allison C, Auyeung B, Baron-Cohen S. Toward brief "red flags" for autism screening: the short autism spectrum quotient and the short quantitative checklist in 1,000 cases and 3,000 controls. J Am Acad Child Adolesc Psychiatry 2012; 51: 202-12.

24. Imran N, Chaudry MR, Azeem MW, Bhatti MR, Choudhary ZI, Cheema MA. A survey of Autism knowledge and attitudes among the healthcare professionals in Lahore, Pakistan. BMC Pediatrics 2011; 11: 107

25. APA-American Psychiatric Association. Diagnostic and statistical manual of mental disorders: DSM-5. American Psychiatric Association Publishing, Arlington 2013.

26. Klin A. Young autistic children's listening preferences in regard to speech: a possible characterization of the symptom of social withdrawal. J Autism Dev Disord 1991; 21: 29-42.

27. Greenspan SI, Brazelton TB, Cordero J, Solomon R, Bauman ML, Robinson R, et al. Guidelines for early identification, screening, and clinical management of children with autism spectrum disorders. Pediatrics 2008; 121: 828-30.

28. Boucher J. Research review: Structural language in autistic spectrum disordercharacteristics and causes. J Child Psychol Psychiatry 2012; 53: 219-33.

29. Centers for Disease Control and Prevention. Autism Spectrum Disorder (ASD) 2018 (cited 2019 January 7). Available from: https://www.cdc.gov/ncbddd/ autism/index.html

30. Nickel RE, Huang-Storms L. Early identification of young children with autism spectrum disorder. Indian J Pediatr 2017; 84: 53-60.

31. Karabekiroğlu K, Cakin-Memik N, Ozcan-Ozel O, Toros F, Öztop D, Özbaran B, et al. DEHB ve Otizm ile İlgili Bilgi Düzeyleri ve Damgalama: Sınıf Öğretmenleri ve Anababalarla Çok Merkezli Bir Çalıșma. J Clin Psy 2009; 12: 79-89.

32. Engelhardt J. The understanding and perceptions of teaching assistants working with children with autism. Good Autism Practice (GAP) 2014; 15: 22- 